\title{
Challenges Associated With the Implementation of Unified Agricultural Extension Services (UAES) Programme in Imo State, Nigeria
}

\author{
${ }^{1}$ Felistas E. Nwarieji $\mathrm{PhD} \&{ }^{2}$ Florence Ifeanyieze $\mathrm{PhD}$ \\ ${ }^{l}$ Department of Agricultural Education, Alvan Ikoku Federal College of Education Owerri, Imo State, Nigeria \\ ${ }^{2}$ Department of Agricultural Education, University of Nigeria Nsukka, Nigeria
}

\begin{abstract}
The study focused on challenges associated with the implementation of unified agricultural extension Services (UAES) programme in Imo State. Specific objectives were to determine the administrative, financial and logistic challenges associated with the implementation of UAES programme. Three research questions guided the study. Null hypotheses were formulated and tested at .05 level of significance. The study adopted survey (descriptive) design and was conducted in Imo State, Nigeria. The population of the study was 22,988 comprising of 22,880 farmers and 108 extension agents in the study area. Total samples of 336 were used consisting of 226 contact farmers and 108 extension agents. The instrument for data collection was Structured Questionnaire complemented by the Focused Group Discussion (FGD) guide. The questionnaire comprised items arranged in clusters. The instrument was face validated by five experts and the internal consistency of the instrument was established using Cronbach alpha method which yielded the reliability coefficients of 0.70 . The instruments were administered through personal contacts with the help of six assistants. The data was analyzed using mean, standard deviation and t-test statistics. Information collected from the focused group discussion was qualitatively analyzed. The findings of the study revealed that Administrative constraints include inadequate market for disposing farm produce, poor coordination of activities of farmers, inadequate training of extension staff; Financial constraints include high cost of adoption of technology, inadequate finance; and Logistics constraints include low level of education, use of traditional implements were the challenges associated with implementation of UAES programme. Based on the findings of the study, conclusions were drawn and recommendations made which include among others the need for adequate provision of agricultural inputs at a subsidized rate and training of extension agents for effective implementation of UAES programme in order sustain agricultural production in Imo State, Nigeria.
\end{abstract}

Keywords: Challenges, Implementation, Unified Agricultural Extension Services

\section{Introduction}

Agricultural extension is an applied behavioural science, which is applied to bring about desirable changes in the behavioural complex of farming community, usually through various strategies and programmes of change, by applying latest scientific and technological innovation. Agricultural extension is the process whereby the results of research are taken to farmers and problems of farmers taken to research institutions for solution (Unamma, 2000). Agricultural extension is aimed at providing farmers with the necessary education; skills and information to enable them to take effective farm management decisions for enhancing their daily practices. Agricultural extension grew out of a national need for the application of scientific knowledge in farming. Agricultural extension seeks to influence the behaviour of rural people through education and information exchange. It is the conscious use of communication technique to help people form sound opinions and make good decisions about farming. Agricultural extension services are carried out by trained staff of extension agencies referred to as extension agents.

Agricultural extension agents are those who give information and guidance to the public on community, youth and human development issues as well as agricultural, environmental, economic and rural concerns. Agricultural extension agents teach improved methods to farmers, ranchers, families and youth, as well as collect, analyze and evaluate agricultural data in order to plan and develop techniques that will assist farmers in solving problems. Ileji (2010) defined an extension agent as a knowledgeable, practically skilled and proficient worker in agriculture who is involved in disseminating information to farmers and assisting them to practice innovations from research institutions. Extension agent is the main axis from which agricultural development process expands (Abdelhakam, 2005).For the purpose of this study, an extension agent is an individual who is trained in different areas of agriculture with responsibility of investigating the problems of farmers, through research institutes and bringing back the solutions to the farmers for implementation. 
Implementation, according to Webster (2010) means the act of carrying out tasks, in order to give practical effect for ensuring actual achievement by concrete measures. Implementation in the context of this study is the execution of all the activities of UAES by the extension agents and farmers to enhance food production. UAES adopts certain strategies for the achievement of programme objectives. To ensure implementation of agricultural programme, appropriate mechanism must be put in place to remove all constraints and bottlenecks that will affect its realization of goals and objectives.

In Nigeria, various efforts have been made by successive governments to improve the food needs of the nation by involving several agricultural extension agencies in the mid-seventies before the World Bank Assisted Agricultural Development Projects (WBADPS) were introduced (Mijindadi, 1992). The Agricultural Development programmes adopted by the previous governments in Nigerian varied in contents and methods which according to Ayichi (1995), included: Rural Banking scheme (1978), The Green Revolution (GR) 1980, Directorate of Food, Road and Rural Infrastructure (DFRRI) 1986, National Directorate of Employment (NDE) 1986, Better Life for Rural Women Programme 1987, and National Agricultural Land Development Authority (NALDA) 1991. Also, efforts were made by several past governments to improve agricultural production through the provision of support services to the farmers known as Unified Agricultural Extension Services (UAES). Oyebanji (2000) defined Unified Agricultural Extension Services as the parallel extension service that is replaced by the provision of extension services through an institution, which will have full administrative control over the entire extension spheres covering crops, livestock, fisheries, agro forestry etc. Thus UAES covers a wide range of activities and programmes that share common objectives of removing the observed food deficit in Nigeria.

Unamma (2004) explained UAES as the organization of the federal and state ministries responsible for agricultural extension organized in such a way that duplicating activities' of the various departments comprising livestock, fisheries, agro-forestry, on- farm activities and related resources are transferred to one extension service body which is Agricultural Development Programme (ADPs). The author maintained that unification of extension services means that the non-crop-based technologies were introduced to the same farmers who had received appropriate messages on crop-based ones. This implies that there is need to ensure that the new noncrop-based messages are synchronized with the crop-based technologies so as not to confuse the farmer. Contextually, UAES is the bringing together of all extension activities into a single line of command to be implemented by the ADPs.

At the establishment period of UAES, all State of the federation were mandated to merge all extension services as a matter of urgency to boost food production. The specific objectives of UAES were: Provision of training and retraining of extension agents and farmers, provision of inputs to farmers, provision of fund for the implementation of the UAES programme, dissemination of improved agricultural innovations to farmers. These basic objectives of UAES were to motivate farmers into adopting proven farming technologies with a view to achieving significant increase in food production and marketing in addition to raising standard of living of the rural farmers. The agricultural sector itself requires a significant transformation such that crop yields and incomes are greatly increased. Such transformation cannot be achieved without the adoption of modern technologies embodied in improved seeds, fertilizers, water management, and better agronomic practices.

Most farmers are passive receptors of information and less concerned on adoption of technologies. Imo State Annual Report (2014) indicated that farmer's involvement and participation in technology development is very low and $90 \%$ of Imo State indigenes particularly in rural areas engage in agriculture while $58 \%$ of the urban populace are poor despite large budgetary allocations. The report concluded that since the establishment of UAES in the state poverty continued to pose problems in the state. The UAES extension strategy remains basically top-down in approach and the farmer also still basically remain passive receptors of information, which may not necessarily meet his/her needs. Since the establishment of UAES, poverty has continued to pose a serious threat to our national survival, that, its eradication or reduction to the barest minimum has become a matter of urgency. This has resulted in the government shifting benchmarks without investigating the problems militating against the effective implementation of the programme objectives. It therefore becomes necessary to examine the challenges associated with the implementation of unified agricultural extension services (UAES) programme in Imo state, Nigeria.

\section{Objectives Of Study}

The purpose of this study was to determine the challenges associated with the implementation of UAES programme in Imo State. Specifically the study sought to determine the:

1. Administrative challenges in the implementation of UAES programme

2. Financial challenges in the implementation of UAES programme

3. Logistics challenges in the implementation of UAES programme 


\section{Hypotheses}

$\mathbf{H O}_{1}$ : There is no significant difference in the mean ratings of contact farmers and extension agents on the administrative challenges associated with the implementation of UAES programmein Imo State.

$\mathbf{H O}_{2}$ : There is no significant difference in the mean ratings of contact farmers and extension agents on the financial challenges associated with the implementation of UAES programme in Imo State.

$\mathbf{H O}_{3}$ : There is no significant difference in the mean ratings of contact farmers and extension agents on the logistic challenges associated with the implementation of UAES programme in Imo State.

\section{Material And Methods}

The study adopted a survey research design. A survey research design in the view of Anyakaoha (2009) uses questionnaires, interviews, observations etc in order to determine the opinions, attitudes, preferences and perception of persons. The design was considered appropriate since the study obtained data from farmers and agricultural extension agents through the use of questionnaire. The study was conducted in Imo State. Imo State three agricultural zone comprised of Orlu, Owerri and Okigwe with 27 local government. The state is agrarian noted for food crop production. The population of the study was 22,988 comprising of 22,880 farmers and 108 extension agents in the study area (ADP field reports, 2014). A multistage stratified random sampling techniques as well as proportionate random sampling were employed in selecting the respondents. In all, 228 contact farmers were randomly selected. The total sample size for the study was 228 plus 108 extension agents/personnel giving a total of 336 respondents. This consisted of 226 contact farmers and 108 extension agents.

A structured questionnaire consisting of twenty nine items was used to elicit information from the respondents. The instrument was subjected to face validation by five experts. The instrument for data collection was Structured Questionnaire complemented by the Focused Group Discussion (FGD) guide. The focused group discussion guide was used to elicit qualitative information from the contact farmers and extension agents. The instruments were administered through personal contacts with the help of six assistants. The reliability of the instrument was established using Cronbach alpha statistical tool which yielded the reliability coefficients of 0.70. Mean and standard deviation was used to answer research questions. Nominal values were assigned to different scaling items of the questionnaire and the corresponding mean scores were interpreted using real limit of numbers. Any item statement whoseboundary limit is 3.5 - 4.00 was regarded as Strongly Agree (SA); 2.5 3.49 Agree (A); 1.50 - 2.49 Disagree (D) and 1.00 -1.49 as Strongly Disagree (SD). t-test statistics was used for testing the null hypotheses at probability of .05 level of significance. The null hypothesis was upheld for any item whose t-calculated was less than the t-table of 1.96 at .05 level of significance, otherwise the item was rejected.

\section{Research Question 1}

\section{Results And Discussion}

What are the Administrative challenges Associated with the Implementation of UAES Programme?

The data answering research question and testing the hypotheses were presented in Table 1

Table 1: Mean Ratings, Standard Deviation and t-test Analysis of the Mean Responses of Famers and Extension Agents on the administrative challenges Associated with the Implementation of UAES Programme in Imo State

\begin{tabular}{|c|c|c|c|c|c|c|c|c|}
\hline \multirow[t]{2}{*}{$\mathbf{S} /$} & \multirow[t]{2}{*}{ Item Statement } & \multirow[t]{2}{*}{$\overline{\mathbf{x}}$ Remark } & \multicolumn{2}{|c|}{$\begin{array}{l}\text { Farmers } \\
n_{1}=228\end{array}$} & \multicolumn{2}{|c|}{$\begin{array}{l}\text { Extension agents } \\
\mathrm{n}_{2}=108\end{array}$} & \multirow[t]{2}{*}{$\begin{array}{l}\text { Sig (2- } \\
\text { tailed) }\end{array}$} & \multirow[t]{2}{*}{ Remar } \\
\hline & & & $\bar{x}_{1}$ & S.D & $\overline{\mathrm{x}}_{2}$ & S.D & & \\
\hline 1 & $\begin{array}{l}\text { Inadequate market for } \\
\text { disposing farm produce }\end{array}$ & 3.48Agree & 3.50 & 0.52 & 3.45 & 0.86 & 0.511 & $\mathrm{NS}$ \\
\hline 2 & $\begin{array}{l}\text { Poor coordination of } \\
\text { activities of farmers }\end{array}$ & $\begin{array}{l}\text { 3.52StronglyAgr } \\
\text { ee }\end{array}$ & 3.48 & 0.55 & 3.62 & 0.59 & 0.045 & $S$ \\
\hline 3 & $\begin{array}{l}\text { Inadequate training of } \\
\text { extension staff }\end{array}$ & $\begin{array}{l}\text { 2.56StronglyAgr } \\
\text { ee }\end{array}$ & 2.81 & 0.84 & 2.03 & 0.98 & 0.000 & $S$ \\
\hline 4 & $\begin{array}{l}\text { Technologies } \\
\text { compatible with farmers } \\
\text { needs }\end{array}$ & 3.51Agree & 3.51 & 0.59 & 3.50 & 0.72 & 0.930 & NS \\
\hline 5 & $\begin{array}{lr}\text { Inadequate } & \text { personnel to } \\
\text { disseminate } & \text { relevant } \\
\text { agricultural technologies }\end{array}$ & 3.49 Agree & 3.58 & 0.54 & 3.30 & 0.87 & 0.000 & $S$ \\
\hline 6 & $\begin{array}{l}\text { Technologies } \\
\text { compatible with farmers }\end{array}$ & 3.67StronglyAgr & 3.63 & 0.51 & 3.76 & 0.47 & 0.021 & $\mathrm{~S}$ \\
\hline
\end{tabular}


Challenges Associated With The Implementation Of Unified Agricultural Extension Services...

\begin{tabular}{|l|l|l|l|l|l|l|l|l|}
\hline & socio-cultural life & ee & & & & & & \\
\hline 7 & Delay in input supply & $\begin{array}{l}3.64 \text { Strongly } \\
\text { Agree }\end{array}$ & 3.58 & 0.59 & 3.76 & 0.51 & 0.008 & $\mathrm{~S}$ \\
\hline 8 & $\begin{array}{l}\text { High turnover of extension } \\
\text { staff }\end{array}$ & 3.26 Agree & 3.03 & 0.90 & 3.77 & 0.54 & 0.000 & $\mathrm{~S}$ \\
\hline 9 & $\begin{array}{l}\text { Lack of mobility for } \\
\text { extension staff to deliver } \\
\text { service }\end{array}$ & 3.49 Agree & 3.45 & 0.67 & 3.58 & 0.80 & 0.109 & $\mathrm{NS}$ \\
\hline 10 & $\begin{array}{l}\text { Bureaucracy in } \\
\text { government services }\end{array}$ & 3.25 Agree & 3.51 & 0.62 & 2.70 & 1.03 & 0.000 & $\mathrm{~S}$ \\
\hline 11 & $\begin{array}{l}\text { Inefficient } \\
\text { rendered by extension staff }\end{array}$ & 3.03 & 0.86 & 3.39 & 0.94 & 0.001 & $\mathrm{~S}$ \\
\hline 12 & $\begin{array}{l}\text { Lack of training facilities } \\
\text { for } \\
\text { dissemination technology }\end{array}$ & 3.49 Agree & 3.36 & 0.74 & 3.78 & 0.65 & 0.000 & $\mathrm{~S}$ \\
\hline 13 & $\begin{array}{l}\text { Non- payment of hazard } \\
\text { allowance }\end{array}$ & $\begin{array}{l}3.58 \text { Strongly } \\
\text { Agree }\end{array}$ & 3.60 & 0.52 & 3.54 & 0.92 & 0.503 & $\mathrm{NS}$ \\
\hline 14 & $\begin{array}{l}\text { Inadequate remuneration } \\
\text { of transport allowance }\end{array}$ & 3.38 Agree & 3.48 & 0.68 & 3.17 & 1.02 & 0.001 & $\mathrm{~S}$ \\
\hline 15 & $\begin{array}{l}\text { Lack of regular } \\
\text { training/in-service training } \\
\text { of staff }\end{array}$ & $\begin{array}{l}2.98 \text { StronglyAgr } \\
\text { ee }\end{array}$ & 3.15 & 0.86 & 2.61 & 0.70 & 0.000 & $\mathrm{~S}$ \\
\hline
\end{tabular}

Note: $\overline{\mathrm{X}}=$ Mean 1; Mean2; SD1=Standard Deviation1; SD2= Standard Deviation2; N1=Number of Farmers; N2= Number of Extension Agents; Sig=Significance Level; NS = Not significant

The two groups of respondents agreed that all the items are the administrative challenges associated with the implementation of UAES programme. This is because their mean values ranged from $2.56-3.58$ which is above the above the cut-off point of 2.50. The Table also showed that the standard deviation (SD) of the items ranged from $3.14-3.98$. This indicated that the respondents were not too far from the mean and from the opinion of one another in their responses.

The Table above also show that the four items had their t-calculate value ranged 0.503 to 0.109 at probability of .05 (two tail test) this indicated that $t$-calculated of each item is lower than the table value of 1.96.The result also revealed that there was a significant difference in the mean responses of farmers and extension agents on eight items since their exact probability level ranges from 0.000 to 0.045 which is less than 0.05 level of significance, the null hypothesis of no significance difference was rejected at .05 level of significance for the items. This indicated that bureaucracy in government, inefficient services rendered by extension staff, lack of training facilities for technology dissemination, non- payment of hazard allowance among others were administrative challenges associated with the implementation of Unified Agricultural extension Services (UAES) programme in Imo State.

\section{Research Question 2}

What are the Financial challenges associated with the Implementation of UAES Programme in Imo State The data answering research question and testing the hypotheses were presented in Table 2

Table 2: Mean Ratings, Standard Deviation and t-test Analysis of the Responses of Famers and Extension Agents on Financial Challenges Associated with the Implementation of UAES Programme in Imo State

\begin{tabular}{|l|l|l|l|l|l|l|l|l|}
\hline S/ & & & $\overline{\mathbf{x}}$ Remark. & \multicolumn{2}{|l|}{$\begin{array}{l}\text { Farmers } \\
\mathbf{n}\end{array}$} & & $\begin{array}{l}\text { Extension gents } \\
\mathbf{n}_{\mathbf{1}}=\mathbf{2 2 8}\end{array}$ & \multicolumn{2}{l}{$\begin{array}{l}\text { Sig(2- } \\
\text { tailed) }\end{array}$} & $\begin{array}{l}\text { Remar } \\
\mathbf{k}\end{array}$ \\
\cline { 4 - 9 } & & $\overline{\mathbf{x}}_{\mathbf{1}}$ & $\mathbf{S . D}_{\mathbf{1}}$ & $\overline{\mathbf{x}}_{\mathbf{2}}$ & $\mathbf{S . D}_{\mathbf{2}}$ & & \\
\hline 1 & $\begin{array}{l}\text { High cost of adoption of } \\
\text { technology }\end{array}$ & $\begin{array}{l}3.60 \text { Strongly } \\
\text { Agree }\end{array}$ & 3.52 & 0.69 & 3.78 & 0.54 & 0.001 & $\mathrm{~S}$ \\
\hline 2 & Inadequate finance & 3.14 Agree & 3.03 & 0.86 & 3.39 & 0.94 & 0.001 & $\mathrm{~S}$ \\
\hline 3 & $\begin{array}{l}\text { Inadequate collateral } \\
\text { facilities for borrowing }\end{array}$ & 3.72 Agree & 3.69 & 0.49 & 3.78 & 0.44 & 0.091 & $\mathrm{NS}$ \\
\hline 4 & $\begin{array}{l}\text { High rate of loan } \\
\text { delinquency }\end{array}$ & 3.38 Agree & 3.48 & 0.68 & 3.17 & 1.02 & 0.002 & $\mathrm{~S}$ \\
\hline
\end{tabular}


Challenges Associated With The Implementation Of Unified Agricultural Extension Services...

\begin{tabular}{|l|l|l|l|l|l|l|l|l|}
\hline 5 & $\begin{array}{l}\text { Inadequate sensitization } \\
\text { of farmers on loan }\end{array}$ & $\begin{array}{l}3.61 \text { Strongly } \\
\text { Agree }\end{array}$ & 3.52 & 0.52 & 3.81 & 0.46 & 0.092 & NS \\
\hline 6 & $\begin{array}{l}\text { Diversion of agricultural } \\
\text { funds }\end{array}$ & 3.45 Agree & 3.48 & 0.54 & 3.65 & 0.65 & 0.000 & $\mathrm{~S}$ \\
\hline 7 & Government inference & 3.26 Agree & 3.03 & 0.90 & 3.77 & 0.54 & 0.000 & $\mathrm{~S}$ \\
\hline
\end{tabular}

The two groups of respondents agreed that all the items are the financial challenges associated with the implementation of UAES programme. This is because their mean values ranged from $3.14-3.70$ which is above the cut-off point of 2.50. The table also showed that the standard deviation (SD) of the items ranged from $0.49-$ 0.90. This indicated that the respondents were not too far from the mean and from the opinion of one another in their responses.

The Table above also show that the two items had their t-calculate value ranged 0.91 to 0.92 at probability of 0.05 (two tail test) this indicated that t-calculated of each item is lower than the table value of 1.96. The result also revealed that there was a significant difference in the mean responses of farmers and extension agents on five items. Since their exact probability level ranges from 0.000 to 0.002 which is less than .05 level of significance, the null hypothesis of no significance difference was rejected at .05 level of significance for the items. This indicated that high cost of adoption of technology, high rate of loan delinquency, government inference were financial challenges associated with the implementation of UAES programme in Imo State.

\section{Research Question 3}

What are the Logistics challenges associated with the Implementation of UAES Programme in Imo State? The data answering research question and testing the hypotheses were presented in Table 3

Table 3: Mean Ratings, Standard Deviation and t-test Analysis of the Responses of Famers and Extension

Agents on Logistic Challenges Associated with the Implementation of UAES Programme in Imo State.

\begin{tabular}{|c|c|c|c|c|c|c|c|c|}
\hline \multirow[t]{2}{*}{$\begin{array}{l}\mathbf{S} / \\
\mathbf{N}\end{array}$} & & \multirow[t]{2}{*}{$\overline{\mathbf{X}}$ Remark } & \multicolumn{2}{|c|}{$\begin{array}{l}\text { Farmers } \\
n_{1}=228\end{array}$} & \multicolumn{2}{|c|}{$\begin{array}{l}\text { Extension gents } \\
\mathbf{n}_{\mathbf{2}}=\mathbf{1 0 8}\end{array}$} & \multirow[t]{2}{*}{$\begin{array}{l}\text { Sig } \\
\text { (2-tailed) }\end{array}$} & \multirow[t]{2}{*}{$\begin{array}{l}\text { Rema } \\
\text { rk }\end{array}$} \\
\hline & & & $\overline{\mathrm{X}}_{1}$ & S.D 1 & $\overline{\bar{X}_{2}}$ & S.D 2 & & \\
\hline 1 & $\begin{array}{l}\text { Low level of education } \\
\text { of the farmers }\end{array}$ & $\begin{array}{ll}3.55 & \text { Strongly } \\
\text { Agree } & \end{array}$ & 3.51 & 0.50 & 3.65 & 0.65 & 0.033 & $\mathrm{~S}$ \\
\hline 2 & Political influence & $\begin{array}{ll}3.56 & \text { Strongly } \\
\text { Agree } & \end{array}$ & 3.48 & 0.51 & 3.75 & 0.50 & 0.000 & $S$ \\
\hline 3 & $\begin{array}{l}\text { Use of traditional } \\
\text { implements }\end{array}$ & 3.45 Agree & 3.43 & 0.54 & 3.49 & 0.84 & 0.471 & NS \\
\hline 4 & $\begin{array}{l}\text { Inefficient extension } \\
\text { delivery system by } \\
\text { extension agents }\end{array}$ & 3.48 Agree & 3.50 & 0.52 & 3.45 & 0.86 & 0.511 & NS \\
\hline 5 & $\begin{array}{l}\text { Inadequate storage and } \\
\text { processing facilities }\end{array}$ & 3.49 Agree & 3.58 & 0.54 & 3.30 & 0.87 & 0.000 & $\mathrm{~S}$ \\
\hline 6 & Lack of access to land & $\begin{array}{ll}3.65 & \text { Strongly } \\
\text { Agree } & \end{array}$ & 3.54 & 0.51 & 3.89 & 0.51 & 0.000 & $S$ \\
\hline 7 & $\begin{array}{l}\text { Uncertainty of weather } \\
\text { due to climate change. }\end{array}$ & 2.98 Agree & 3.15 & 0.86 & 2.61 & 0.70 & 0.000 & $S$ \\
\hline
\end{tabular}

The two groups of respondents agreed that all the items are the logistic challenges associated with the implementation of UAES programme. This is because their mean values ranged from $2.98-3.65$ which is above the above the cut-off point of 2.50. The table also showed that the standard deviation (SD) of the items ranged from $0.50-1.14$. This indicated that the respondents were not too far from the mean and from the opinion of one another in their responses.

The table above also show that the six items had their t-calculate value ranged from 0.000 to 0.471 at probability of 0.05 (two tail test) this indicated that t-calculated of each item is lower than the table value of 1.96. Which indicated the null hypothesis of no significance difference was accepted at 0.05 level of significance for the items. This indicated that Lack of access to land, uncertainty of weather due to climate change, inadequate storage and processing facilities among others were logistic challenges associated with the implementation of UAES programme in Imo State. 
Table 4 Summary of t-test Table on the Responses of Famers and Extension Agents on the Challenges Associated with the Implementation of UAES Programme in Imo State

\begin{tabular}{|l|l|l|l|l|l|l|l|}
\hline Respondents & $\mathrm{N}$ & $\overline{\mathbf{X}}$ & S.D & df & t-cal & Sig. & Remark \\
\cline { 1 - 7 } Farmers & 226 & 3.44 & 0.34 & 332 & 1.96 & 0.227 & NS \\
\cline { 1 - 5 } Extension Agents & 108 & 3.48 & 0.31 & & & & \\
\hline
\end{tabular}

The results form Table 4 shows that there was no significance difference in the mean responses of the farmers and extension agents on the Problems Associated with the Implementation of UAES Programme. The null hypothesis of no significance difference was accepted at 0.05 level of significance for the items since the significance is 0.227 which is more than 0.05 level of significance. This shows that the professional ability of the farmers and the extension agents did not significantly affect their opinion on the problems associated with the implementation of UAES Programme.

\section{Discussion Of Findings}

The data generated and analyzed from the research question and hypotheses from farmers and extension agents confirmed that administrative constraints include technologies not compatible with farmer's needs, inadequate personnel to disseminate relevant agricultural technologies among others; financial constraints include inadequate facilities for borrowing, High rate of loan delinquency and logistic constraints among others includes political influence, inadequate storage and processing facilities, lack of access to land are the challenges associated with implementation UAES programme in Imo state. The findings of this study agreed with the submission of Eme (2005) who noted that farmers who produce the bulk nations agricultural output lack fertilizers, chemicals, high yielding varieties and animal breeding. Also, lack of good roads, electricity, and drinking water and health facilities are grossly inadequate. The findings of this study were in agreement with the findings of Dandu, Anum and Madukwe (2009) who carried out a study on the Extension capability of Benue State Agricultural and Rural Development Authority. The authors found out that the agency had inadequate subject matter specialist who also lacked specialty training. The study also revealed that all the agency's extension workers were middle level trained staff.

The findings on financial constraints in this study is in line with the view of Awoyemi (2010) who noted that if the small scale farmers are to grow to become medium and eventually large scale farmers they must have among other incentives supply of credit for short, medium and long term. The findings also agree with the submission of Atala and Akokoyo (1993) who pointed out that agricultural loan and credits are easier obtained by civil servants and military officers who take farming as a lobby and can easily provide stipulated collaterals than the full time farmers to whom lip service is paid. Food and Agricultural Organization (FAO) (1991) remarked that the issue of funding extension continues to be the most difficult problem faced in the implementation of UAES programme. The findings of this study were also in conformity with the finding of Mejeha (2001) who in his study on Institutional Financing of Agricultural Production in Nigeria Problems and Policy Issues found out that agricultural credit policies were implemented through financial institution and total loans granted to agriculture were low, when compared with loans to other sectors.

Also Mbah (2001) in his study on Farm Credit Sources and Problems in Credit Acquisition in Yakurr Local Government Area, Cross River State Nigeria found out that informal sources constituted as important source of credit to small holder farmers, and the demand for agricultural credits were very high in small farm communities it also revealed the major problems encountered included lack of collateral security to obtain the loan, insufficient funds illiteracy and high interest rates. Igwe, Ezedimma and Nwajiuba (2009) conducted a study on Strategies for financing Nigeria's Agriculture in the Post World Bank Era: A case Study of the Agricultural Development project in Imo state. The study found out that the agricultural development programmes in Nigeria face challenging times ahead with the withdrawals of World Bank funding.

On logistic constraints, the findings are in line with the view of Feder (2001) who pointed out that a plausible reason for lack of support by politicians and government officials to agricultural extension investment is the absence of the kind of political pay offs that can be earned from other public outlays. However, Idachaba (2010), observed that there are problems of inappropriate, unrealistic or unworkable policies. Furthermore , mobility problems in unified Agricultural extension service were more of lack of spare parts, field and poor maintenance of available vehicle often times where there is mobility, transport allowances were unduly delayed for such reasons as priority to contractors who supply calendars, diaries and services. Feder (2001) posted that a plausible reason for lack of adequate support by politicians and officials to Agricultural extension investment is the absence of the kind political pay offs that can be earned from other public outlay that has visible inputs such as double cropping that follows in transport cost. In line with this Okereke (2010) remarked that both the distribution of farm inputs and farm output are constrained by poor network of feeder roads and absence of effective market intelligence. Also production systems use by farmers are characterized by low efficiency, consequently, the majority of the farming communities cultivate land under input-starved conditions. 
Moreover, traditional processing and storage facilities have been unable to cope effectively with increased agricultural production. Shalaby, Al-Zahrani, Baig, Straquadine and Aldosari (2011) conducted a study on threats and challenges to sustainable agriculture and rural development in Egypt: implications for agricultural extension. The findings of the study revealed that despite positive and significant contributions of agriculture to food security, prominent challenges include land and water issues; old cultivation techniques; lack of information on marketing; poverty; degradation of natural resources and environmental issues; population growth; inadequate support services; framework and institutional constraints; and lack of agricultural and rural development policies. The findings of the authors in their various research activities helped to support the justification of the finding of this study for effective implementation of Unified Agricultural Extension programme for sustainable agricultural production in Imo State, Nigeria.

Qualitative responses of farmers and the extension agents on the focus group discussion on challenges associated with the implementation of UAES programme revealed that all the farmers and the extension agents agreed that major constraints includes; inadequate storage and processing facilities, land tenure, inadequate credit facilities, late supply of inputs, lack of access roads, inadequate distribution of inputs, poor marketing of agricultural produce, inadequate communication, Mobility, finance, hazard allowance/kilometric, inadequate staff accommodation, and imposition of responsibilities

\section{Conclusion}

The issue of sustainable food production has been the primary focus of the Nigeria Government (Imo State inclusive). This has led to establishment of programmes that will enhance food production which UEAS is one such programmes. The continued shortage of food supply and high cost of food has called for the study challenges associated with implementation UAES programme in Imo state. The study identified amongst others lack of credit facilities, loan default, lack of basic infrastructure, lack of securities, and technical expertise as the challenges associated with implementation UAES programme in Imo State.

\section{Recommendations}

1. Government should provide agricultural inputs at a subsidized rate to farmers.

2. Policy makers should formulate policies that will promote the adoption of innovation by farmers.

3. Government at the state and federal level should allocate adequate funds to this important activity.

\section{References}

[1]. Abdelhakam, A.M., (2005), "Agricultural Extension in Egypt.Chapter II. In. Proc. FAO Regional Workshop on Options of Reform for Agricultural Extension in the Near East". Amman, Jordan 2-4 October, 2004. Food and Agriculture Organization of the United Nations Regional Office for the Near East, Cairo, pp. 22-26.

[2]. Anyakaoha, E. U. (2009), "Developing Research Skills: Concepts and Conceptual Framework". Nsukka: Great AP Express publishers Ltd.

[3]. Ayichi, D. (1995), "Agricultural Transfer for Sustainable rural Development in Nigeria: Concepts, Processes and Prospects". Lagos: Auto century Publishing Company.

[4]. Dandu, S. Anum, J.A. \& Madukwe, M.C. (2009), "Extension Capability of Benue State Agricultural Development Authority Publication of Faculty of Agriculture". Nassarawa Sate University. 5(1).55-56.

[5]. Feeder, G.A. (2001), "Agricultural Extension: Challenges and the Ingredients for solution knowledge Generation and Technical Change". Institution Innovation in Agriculture. Bestin Mass

[6]. Food and Agricultural Organization (FAO), (1991), "Report of the Global Consultation on Agricultural extension Rome: FAO.

[7]. Idachaba, F.S. (2010), "State federal Relation in Nigerian Agricultural MADLA". Discussion Paper The World Bank; Washington D.C. 8, 4 .

[8]. Igwe, H., Ezedinma, C. I. \& Nwajiuba, C. U. (2009), "Strategies for Financing Nigeria Agriculture in the post world Bank era: A Case Study; Proceedings of the $3^{\text {rd }}$ farming system Research and extension workshop in South Eastern Nigeria". Umudike: Imo State Nigeria 270.

[9]. Ileji, A.U. (2010), "Diagnostic Analysis of non-Adoption Variables of Agric Development programme, rice production Technologies among farmers in Anambra State". Nsukka:

[10]. (Unpublished PhD thesis), Department of Vocational Teacher Education (VTE), University of Nigeria Imo ADP, (2011), "Imo State Agricultural Development programme Annual Report Owerri Nigeria".

[11]. Mbah, A. (2001), "Government Budgetary Allocation: A Case Study of the Performance of the Commercial and Merchant Bank's prescribed allocation of credit to Agriculture Sector". Nsukka: A paper presented at the second Biannual Conference of the Nigerian Association of Agricultural Economist, held at the University of Nigeria,. $30-44$.

[12]. Mejeha, R.O (2001), "Institutional Financing of Agricultural Production in Nigeria: Problems and policy Issues". Abeokuta: Proceedings of the $35^{\text {th }}$ Annual Conference of the Agricultural Society of Nigeria. September 16-20. University of Agriculture, , Oyo State Nigeria.

[13]. Okeke, F. O. (2010), "Rural Development in Nigeria: for What and for Whom". Journal of Social Sciences 1( 1). 8085 . 
[14]. Oyebanji, O.O. (2000), “Training and visit Extension system in unified Agricultural Extension Service; Paper presented at the national workshop on unified Agricultural extension service and women in Agriculture, Ijebu Ode.

[15]. Shalaby M. Y., Al-Zahrani K. H., Baig M. B., Straquadine G. S., \& Aldosari F. (2011), "Threats and Challenges to Sustainable Agriculture and Rural Development in Egypt: Implications for Agricultural Extension". The Journal of Animal \& Plant Sciences, 21(3): 2011, Page: 581-588

[16]. Unamma, R. P.A. (2000), "World Bank's Expectations from the Agricultural Development Projects (ADPS)”.Lagos: The World Bank Resident Mission.

[17]. Unamma, R.P.A (2004), "Farming systems in Nigeria". Report of the Benchmark Survey of the Farming systems of Eastern Agricultural Zone of Nigeria.

[18]. Websters, (2010), "Webster's third new International Dictionary". U.S.A: English laws Cambridge, Merriam Webster line. 